\title{
Evaluation of Government Policy on School From Home and its Impact on Parents Stress Level In Bekasi City
}

\author{
Widiyono ${ }^{1}$, Diana Prihadini ${ }^{2}$, Siti Nurbaity ${ }^{3}$, Heksawan Rahmadi ${ }^{4}$, Roby Irvawan ${ }^{5}$ \\ ${ }^{12345}$ Faculty of Administration Science, INSTITUT STIAMI JAKARTA \\ Correspondent: hexawanmaryoto@gmail.com
}

Submitted : September 25,2020 Revised : October 17,2020 Published : October 31, 2020

\begin{abstract}
In accordance with government policies on some provinces, starting Monday (3/16/2020) up to this very moment, the policy of learning/school from home is still being implemented, starting from kindergarten, elementary, junior high and high school levels even to universities. This step was taken by the government to anticipate the spread of a new type of corona virus or Covid-19 within the educational institutions. The direct impact of changes in the learning system, so called 'internet based learning', has forced various parties to follow and being adaptive to this government policy. On the one hand, this gives students and parents in general, the opportunity to approach new learning systems, but on the other hand there are still many lacks of devices and readiness of parents to catch up the system changes that are suddenly applied without stage of socialization and preparation. For educators, especially elementary school teachers to secondary schools and leaders of educational institutions, the policies provide many opportunities as well as a threat, because there are needs of certain preparation for teachers to engage education processe with a completely different pattern from conventional learning. Parents of the students, also facing challenges outside their daily routine and various tasks and responsibilities on office, which almost sudden now have to prepare, even assisting their children in learning through the internet. This certainly has psychological impact on parents' stress. Seeing the above facts, it is deemed necessary to design an education system with a learning pattern at home, which is an internet-based education system that is able to create an atmosphere and learning process that is fun, stimulating, and challenge students to develop themselves optimally in accordance with their talents and abilities, and parents as a companion of their children in the process of learning from home may avoid psychological stress.

Keywords: Government policy; distance learning; school from home; the impact of parents' stress; stress management
\end{abstract}

\section{INTRODUCTION}

The corona virus pandemic has begun to have its impact on the education field, amides of this breakout, the central and regional governments have declared policies to close all educational institutions. These efforts have been taken to prevent the spread of the corona virus. It is hoped that by hold all educational institutions off from carrying out its activities as usual, then the spread of the COVID-19 19 disease can be minimized. The same thing has also been done by various countries affected by the COVID-19 19 disease, lockdown or quarantine policies are carried out in an effort to reduce the interaction of many people who can provide access to the spread of the corona virus. The spread of the corona virus initially had a huge impact on the economic world which was starting to sluggish, but now the impact is also being felt by the world of education. The policies taken by many countries, including Indonesia, by closing all educational activities, have made the government and related institutions have to present an alternative educational process for students starting from 
Evaluation of Government Policy on School From Home and its Impact on Parents Stress Level In Bekasi City Widiyono, Prihadini, Nurbaity, Rahmadi, \& Irvawan

kindergarten, elementary school to tertiary institutions, unable to carry out face-to-face teaching and learning processes.

Around 25 millions primary school children in Indonesia are now studying under the threat of the COVID-19 pandemic. As been done by many countries, to prevent the transmission of the corona virus in schools, the Minister of Education and Culture issued a circular dated March 24, 2020 which regulates the implementation of education during the emergency period under the spread of coronavirus. The "Learning from Home" policy, this is appropriate to prevent the spread of COVID-19 in the school environment, online learning patterns in accordance with government policies through the Ministry of Education must be interpreted by teachers wisely. One of them is providing learning materials for students so as not to feel monotonous and not difficult for both students and their parents who accompany their children during learning process.

According to observations of homeschooling practitioner Hanung Soekendro, he said that the impact of teaching and learning activities at home for a long time due to the Coronavirus outbreak can cause boredom to students. Based on temporary observations, it was found that stress was not only experienced by children when carrying out the distance learning process (PJJ) online which was applied during the COVID-19 pandemic recently. Parents might experience the same thing. One of the causes of parental stress in this context is that many parents do not really understand the syllabus of their children but are being forced to accompany and must explain or teach something that they are not good at, or limited knowledge to it. On the other hand, parents play very important roles on the online learning process. Therefore, parents should avoid stressed and make the online learning process effective but fun.

Another obstacle is found that not all students or students are accustomed to learning via online as well as limited internet access. Moreover, many parents as the main companion in PBM are still not proficient in using internet technology or social media, especially in the Bekasi area.

According to Vedung, "Evaluation is the process of determining the merit, worth, and value of things". Then Jones quotes Carol H. Weiss (1991: 356): Evaluation is an elastic word that includes all kinds of considerations. The use of the word in the general sense is a term to weigh benefits. A person observes and examines a phenomenon (a person, an object or an idea) based on several explicit and implicit measures. To support this opinion, Jones (1991: 356) briefly states that evaluation is assessing the benefits of government processes and programs.

Stufflebeam and Shinkfield (2007: xxv) argue that: "Evaluation is a vital component of the continuing health of organizations. If evaluations are conducted well, organizations and their people will have the satisfaction of knowing with confidence who elements are strong and where changes are needed. Evaluation therefore is a positive pursuit ". Then, Nugroho (2009: 535-536) argues that the main purpose of evaluation is not to blame, but to see how big the gap is between the achievements and expectations of a public policy. The next task is how to reduce or close the gap. So, evaluation of public policies must be understood as something that is positive. Evaluation aims to find deficiencies and cover up deficiencies.

Dunn (2003: 609-610) says that evaluation provides valid and reliable information about policy performance, namely how far needs, values and opportunities have been achieved through public action; evaluation contributes to clarification and criticism of the values that underlie the selection of goals and targets; and evaluation contributes to the application of 
Evaluation of Government Policy on School From Home and its Impact on Parents Stress Level In Bekasi City Widiyono, Prihadini, Nurbaity, Rahmadi, \& Irvawan

other methods of policy analysis, including problem formulation and recommendations. Then, Chelimsky, Jose Hudson, John Mayne and Ray Thomlison in Evert V Gedung (2009: 101) argue that there are four evaluation objectives, namely to increase knowledge, improve delivery program, reconsider program direction, and provide for accountability.

Hainz Eulau and Kenneth Prewitt in Jones (1991: 47) define policy as a permanent decision which is characterized by the consistency and repetitiveness of the behavior of those who make and those who comply with these decisions. Then, Nakamura and Smallowood (1980: 31) sees public policy as a set of instructions to policymakers describing goals and ways to achieve those goals.

Anderson (1978: 3) states: "Public policies are those developed by governmental bodies and official" s. Dye in Nugroho (2009: 84) sees public policy as "what government does, why they do it, and what difference it makes" .

Dunn (2004: 1) says that public policy is "a complex pattern of interdependent collective choice, including decisions not act, made by governmental bodies and official". Then, Nugroho (2009: 85) argues that public policy is a decision made by the state, especially the government, as a strategy to realize the objectives of the State concerned. Public policy is a strategy to lead people in the early days, enter society during a transition period, to lead to the society they aspire to.

According to the National Endowment For The Arts or NEA (2000), outcomes are the benefits that occur to participants of a project; they represent the impact that the project has on participants. Typically, outcomes represent a change in behavior, skills, knowledge, attitude, status or life condition of participants that occur as a result of the project. Mustopadidjaja (2002: 45) states that the evaluation of policy implementation is an activity in policy process management which is carried out at the monitoring, implementation, supervision or accountability stages. Then, Dunn (2003: 108) argues that the policy outcome is an observed consequence of policy action.

Dunn (2003: 29) states: evaluation does not only produce conclusions about how far the problem has been resolved; but also contributes to clarification and criticism of the values underlying policies, assisting in adjustment and reformulation of issues. Then Sofyan Effendi in Nugroho (2003: 184) argues, in fact public policy evaluation has three scope of meaning, namely evaluation of policy formulation, evaluation of policy implementation and evaluation of policy environment. However, according to Nugroho (2003: 184), the concept in the concept of "evaluation" itself always includes the concept of "performance", so that the evaluation of public policies in the three areas means "post activity". Tilaar and Nugroho (2004: 190) suggest that public policy evaluation has four spheres of meaning, namely evaluation of policy formulation, evaluation of policy implementation, evaluation of policy performance and evaluation of the policy environment. However, according to Winarno (2011: 229), in general, policy evaluation can be said as activities that involve estimating or assessing policies that include substance, implementation and impact.

According to Akbar (2011), learning activities require assistance from parents and others, so that students become enthusiastic in learning. The role of the family, especially both parents, greatly affects the growth and development of children. Parents are the first and foremost people who are capable, and have the right to help their offspring and educate their children. The role of parents is very influential in the family to create emotional bonds with children, create a safe atmosphere at home so that the home is a place for children to return, 
Evaluation of Government Policy on School From Home and its Impact on Parents Stress Level In Bekasi City Widiyono, Prihadini, Nurbaity, Rahmadi, \& Irvawan

become an example for their children, provide discipline and improve children's behavior, create good communication between family members.

Supervision and guidance of parents at home is absolutely necessary because there is guidance from parents, they can supervise and know all the shortcomings and difficulties of children in the learning process. Parents play a major role in teaching, educating, providing guidance and providing learning facilities as well as providing role models for children in accordance with prevailing moral values or behaviors that need to be avoided. Mentoring from parents can also act as a way to increase discipline in learning. Learning children need guidance from parents so that adult attitudes and learning responsibilities grow in children.

Assistance provided by parents at home can increase children's learning motivation in addition to guidance from a teacher. With strong motivation, someone is able to work hard in achieving something. A good motivation to learn is expected to arise in a child.

\section{METHODS}

The research used an exploratory case study method and the research approach used a qualitative case study method which was used to obtain information on the constraints and consequences of the COVID-19 pandemic on teaching and learning activities in primary schools, its impact on the stress level of people or students as the main companion in the PBM process. Sample size is based on achieving depth and richness of description, not sample size. According to Guetterman (2015), sample size is not a matter of representative opinion and views, but rather a matter of information wealth. In this study, respondents were 34 parents as guardians of students. For confidentiality purposes, respondents were given the initials R1, R2, R3 and R4. Semi-structured interviews were conducted and a list of questions compiled for interviews was developed based on related literature. Respondents for this study were teachers and parents of students in an elementary school in Bekasi.

Respondents are parents of elementary school students in Bekasi City. As many as $80 \%$ percent are mothers, the rest are fathers. The age range for the majority is between 35 and 50 years. While the respondent's occupation consists of housewives $(60 \%)$ the rest is divided into traders, part-time workers and office employees. The majority of them have S1 (55\%), Diploma (30\%) and High School (15\%) education. The educational level of students whose parents accompany them are spread across grades 1 to 6 in elementary school.

The primary collection method was by using semi-structured interviews while secondary data were collected from published data such as articles in journals and books. This study is limited to a sample size of 43 respondents who live in Bekasi City. This research is an exploratory case study and the sample was selected using purposive sampling method. In qualitative research, purposive sampling technique is a method used to achieve certain research objectives. There is no limit to the number of respondents to make a purposive sample, as long as the desired information can be obtained and generated (Bernard, 2002). To conduct case study research, Creswell (2013) provides observations and a number of sample size recommendations, which range from no more than four to five cases. In the case study respondents are interviewed until data accuracy is achieved and no more new information can be obtained (Guest et al., 2006; Krysik and Finn, 2010). All respondents answered questions through distributing interview questionnaires. interviews were conducted via online. Analysis and interpretation of data is the most critical part of qualitative research. Guidelines for thematic data analysis (Creswell, 2009) were used. This is considered the most appropriate for any study that seeks to explore several interpretations (Alhojailan, 2012). In a thematic analysis 
Evaluation of Government Policy on School From Home and its Impact on Parents Stress Level In Bekasi City Widiyono, Prihadini, Nurbaity, Rahmadi, \& Irvawan

"all possible interpretations are possible" (Alhojailan, 2012, p. 10). The rationale for choosing thematic analysis is that "a rigorous thematic approach can produce in-depth analyzes that answer specific research questions" (Braun and Clarke, 2006, p. 97). After rigorous analysis, the researcher described the findings, according to 9 main themes. To explore and obtain information on the impact or constraints of the COVID pandemic on the teaching and learning process, several research questions were made, the following questions were asked:

1. What is the average length of time accompanying children in the teaching and learning process at home

2. Are there any constraints on BM learning facilities at home, especially the internet and other facilities such as laptops, Android phones, etc.

3. Who has the biggest role in assisting the children to learn at home to you?

4. Is PBM at home effective enough for children's absorption in receiving knowledge and knowledge from their teachers

5. As a parent who accompanies children in PBM through online, how do you respond

6. Do you enjoy and feel comfortable in teaching PBM for children at home

7. If not what is the reason

8. What are your suggestions regarding the PBM being ordered?

9. How do your children respond to PBM through this online

The data analysis technique used in this research is qualitative data analysis. Qualitative analysis was carried out by means of analysis during data collection and analysis after the data was collected. Analysis during data collection includes: developing field notes, categorizing data, entering data into analysis formats, and developing questions to collect further data, while analyzing after data has been collected. then describes the data that has been analyzed in accordance with the components of the evaluation model, and draws some conclusions.

\section{RESULTS AND DISCUSSION}

\section{Online learning policies are weak at the Implementation stage}

There are still many obstacles in online learning that have led a number of parties to say that the government, in this case the Ministry of Education and Culture (Kemendikbud), has failed to adapt to the era of technological disruption. In fact, the legal umbrella for online learning was established four years ago, but it is still weak in implementation. The standards for implementing online-based learning have actually been regulated in Permendikbud number 22 of 2016 concerning Education Process Standards. But in fact, four years ago there were still many obstacles encountered in online learning, especially facing Covid 19. The rapid spread of the Covid-19 pandemic has caused disruption to the Indonesian education sector where around 25 million students cannot continue their learning activities at school normally.

The Covid-19 crisis shows a large-scale need for state-private partnerships between relevant ministries (Kemendikbud and Kemenag) and telecommunications service providers and their hardware. The partnership can use existing infrastructure to expand the implementation of distance learning across Indonesia.

The Ministry of Education and Culture (Kemendikbud) and the Ministry of Religion (Kemenag) need to consider implementing distance learning that is tailored to the different characteristics of regions in Indonesia. Distance learning adds barriers to students who already have difficulty accessing education, so the diversification of delivery media other than the internet needs to be considered. Options could be a radio program or using postal services for areas with low connectivity. 
Evaluation of Government Policy on School From Home and its Impact on Parents Stress Level In Bekasi City Widiyono, Prihadini, Nurbaity, Rahmadi, \& Irvawan

Technology, more specifically the internet, smart phones and laptops are now widely used to support distance learning. One of the largest telecommunications service providers in Indonesia recorded an increase in broadband flows by $16 \%$ during the Covid-19 crisis, due to the sharp increase in the use of distance learning platforms.

However, this disruption to the traditional education system has disadvantaged students who come from underprivileged families and who live in rural areas, especially in the Bekasi area. These are students who, even under normal conditions, already face barriers to accessing education. Now they need to face additional barriers that arise from inequality in accessing technology infrastructure.

\section{Private Sector Response to the Covid-19 Crisis}

Private stakeholders in the education sector have provided various ready-made solutions to support the implementation of distance learning. The Ministry of Education and Culture began collaborating with online learning service providers and technology companies (Kemendikbud, 2020). Several learning platforms have provided free access to some, or even all, of their content during this time of the pandemic. Several telecommunication companies also provide free internet quota to access available online learning platforms (Budiansyah, 2020).

Not only the business sector, but private schools also adapt to the current situation. Private schools in underprivileged areas of Bekasi (Cheap private schools) implement a semionline method of distance learning. They use a messaging service platform via the WhatsApp application, which is widely used in Indonesia, to carry out class discussions and share assignments and learning materials. Those who do not have adequate devices are encouraged to borrow smartphones or laptops from their relatives.

Cheap private schools attract low fees to educate students who come from underprivileged families, and at the same time these schools also keep them financially independent and not dependent on government budgets (McLoughlin, 2013 cited in Rahman, 2016). These schools are often forgotten in the education system, but in fact they play an important role in educating children who come from underprivileged families by providing cheap and high quality education. Low-cost private schools have very limited resources to switch to distance learning, so the Ministry of Education and Culture must expand its reach to these schools.

\section{Several field findings related to PBM online in the city of Bekasi}

In the city of Bekasi, schools have closed schools since March 2020 until now, from kindergarten, elementary, junior high and high school levels until this step was taken to anticipate the spread of the new type of corona virus or Covid-19 in educational institutions.

Instead, learning that is usually done at school is changed to at home. Students continue to do all school work even at home. Based on the findings in this study, parents who also work from home are asked to supervise and assist the child's PBM process while at home with an average duration of between 2 and 3 hours each day. based on the results of the interview even though it looks fun, learning at home is not something easy for parents. In fact, the majority of the answers were from the parents of the children studying at home but busy parents. In fact, he admitted that he was really stressed when watching and accompanying his child while studying. In addition to the large amount of material, not all lessons are mastered by the parents of students.

There are many other complaints from the parents of students, including that not all parents are able to provide adequate online PBM facilities, both internet networks and other 
Evaluation of Government Policy on School From Home and its Impact on Parents Stress Level In Bekasi City Widiyono, Prihadini, Nurbaity, Rahmadi, \& Irvawan

software. Another complaint from parents of students studying at home, feeling that they are burdened by the cost of internet packages which add to the burden of daily living costs, not to mention the assignments from school, each day the assignment must be sent to the teacher via electronic mail.

Other parents admitted that they were stressed because their children were too relaxed in doing their assignments. While the teacher has announced who has not submitted the assignment. Apparently his son is holding a cellphone (device) while playing games.

While studying at home, the learning system at their children's school is still as usual. The difference is only through classes in the network (online). Not wearing a uniform, and can do tasks while eating.

Another complaint is that many of the teacher's assignments are in English where the parents are not quite used to it so that it is quite confusing, although it is helped by the Google Translate facility. While what is quite mitigating, including for first graders, is that after completing tasks, there is no need to bother picking up. If homework (PR) has been done early, then after that all PB activities have been completed.

Even so, because everyone uses the same cellphone owned by the mother, if all children are still in elementary school, then the cellphone has a very heavy burden so that too much data enters and often "hangs".

Being a supervisor for children who study at home has its own challenges. Namely, how to be disciplined with time.

Another complaint from parents regarding remote PBM is that the readiness of the teacher in teaching both the readiness of teaching materials and how to teach using the internet is deemed not optimal, thus increasing the burden on parents of students in assisting children to study at home.

\section{CONCLUSION}

\section{Adjusting the implementation of distance learning according to regional conditions}

To deal with some of the complaints of parents regarding PBM at home with complaints about limited internet networks and quite expensive quota burdens and adding to the burden of living costs, the government should look for alternative ways besides completing TVRI programs in areas with limited internet access, delivery Learning materials can be done via radio either private radio or RRI. as has been done in other countries such as Argentina and Fiji. The Argentine government provided seven hours of radio content delivered by experienced teachers via the state radio network during the school building closure, while the Fiji government collaborated with two radio stations to provide reading and numeracy lessons for grades I to VIII students as well as for early childhood education (The World Bank, 2020). The Indonesian government can also work with PT Pos Indonesia to help teachers distribute worksheets and modules to students, this practice is taken from positive experiences in France (AFP, 2020).

\section{Set up regional work groups to provide guidance}

With no certainty about the end of the ongoing pandemic, the Ministry of Education and Culture is currently preparing a distance learning plan until the end of the year (CNN Indonesia, 2020). Although distance learning activities are highly dependent on school initiatives and sources of information from the Ministry of Education and Culture, local governments also need to assist schools by establishing task forces that further provide financial assistance outside of BOS and access to recording studios and equipment for schools 
Evaluation of Government Policy on School From Home and its Impact on Parents Stress Level In Bekasi City Widiyono, Prihadini, Nurbaity, Rahmadi, \& Irvawan

and teachers. This task force should pay special attention to low-cost private schools that play an important role in providing education to the urban underprivileged, which have fewer resources than more established public and private schools (Rahman, 2016; Wikaningtyas, 2017).

\section{Develop a supervisory framework and a strategy for BOS use}

MoEC should consider developing a strong supervisory framework to monitor the use of BOS for distance learning. Good supervision not only helps ensure that funds are used according to the ministry's original intentions, but also to identify areas where assistance is most needed. Kemendikbud also needs to consider whether this expansion is temporary or whether there are components that can be adopted permanently.

\section{Provide broader autonomy to school principals}

What parents have most complained about as the findings above is that the expense of parents' budgets is getting bigger, especially for internet packages, so it needs to be considered that BOS funds from the government should be used by schools to support vulnerable families who are struggling with additional expenses to buy internet package and telephone credit,

Broader autonomy in times of emergency such as the Covid-19 crisis is important, especially for public school principals. Its implementation requires both bureaucratic flexibility and better decision-making capacity by principals. Given that the Ministry of Education and Culture has given decision-making authority to individual schools, its authority can be extended to the use of BOS, especially in emergencies. Instead, MoEC should consider incorporating a school management skills budget into the school leadership transformation agenda that MoRA can undertake for schools under its jurisdiction (OECD, 2017; MOEC, 2020c).

\section{Equip teachers with skills to carry out distance learning}

Distance learning has been the most widely felt barrier in the education sector even before the pandemic, but the current crisis has significantly accelerated the adoption of its implementation. It is important to include distance learning skills in future teacher training programs.

The use of information and communication technology has been included in the training curriculum. However, there are doubts about its effectiveness considering its contents are largely irrelevant to distance learning. For the successful adoption of distance learning, teachers need to have not only basic technology skills (such as using computers and being connected to the internet), but also knowledge for using recording devices and software, as well as methods for delivering lessons without face-to-face interaction. These skills will be required when using online learning platforms in Indonesia. More importantly, the gap between the training scenario and execution in the field needs to be minimized.

By considering this, at least able to increase the skills of teachers in teaching with a distance learning pattern so that they are able to teach and transfer knowledge optimally, effectively and efficiently.

\section{Maintain school partnerships with parents}

Partnerships between schools and parents of students in terms of online learning platforms need to be developed and improved, especially in the current Covid-19 Crisis. This needs to be done to find the best solution so that parents feel there is a way out in PBM. 
Evaluation of Government Policy on School From Home and its Impact on Parents Stress Level In Bekasi City Widiyono, Prihadini, Nurbaity, Rahmadi, \& Irvawan

\section{REFERENCES}

Dunn, William N. (2004). Public Policy Analysis: An Introduction, Second Edition, New Jersey: Pearson Prentice Hall.

Dunn, William N. (2003). Pengantar Analisis Kebijakan Publik. Edisi Kedua, Yogyakarta: Gajah Mada University Press.

Direktorat Pembinaan Taman Kanak-kanak dan Sekolah Dasar Direktorat Jenderal Manajemen Pendidikan Dasar dan Menengah Kementerian Pendidikan Nasional. (2009). Potret Hasil Ujian Akhir Sekolah Berstandar Nasional, Jakarta.

Direktorat Pembinaan Pembinaan Usia Dini Ditjen Pendidikan Anak Usia Dini, Nonformal dan Formal Kemendikbud. (2013). Petunjuk Teknis Monitoring dan Evaluasi, Jakarta : Direktorat Pembinaan Usia Dini

http://elearning.unesa.ac.id/tag/penjelasan-tentang-outcomes-sdm

http://elearning.unesa.ac.id/myblog/alim-sumarno/pengertian-outcome

http://www.kebijakankesehatan.co.cc/2010/03/indikator-kinerja-input-proses-output.html

Jones, Charles O. (1991). An Introduction to the Study of Public Policy, diterjemahkan Ricky Istamto, Jakarta: CV. Rajawali.

Jones, Charles O. (1984). An Introduction to the Study of Public Policy,Third Edition, Monterey: Cole Publishing.

Nugroho, Riant. (2004). Kebijakan Publik Formulasi, Implementasi, and Evaluasi, Jakarta: Elek Media Kamputindo.

Nugroho, Riant. (2009). Public Policy, Jakarta: PT. Elex Media Komputindo.

Nasional Lasswell, Harold D. \& Kaplan, Abraham. (1970). Power and Society, New Haven: Yale University Press.

Nasution, S. (2003). Metode Penelitian Naturalistik Kualitatif, Bandung : Tarsito.

Nakamura, R.T \& Smallowood, F. (1980). The Politics of Policy Implementation, New York: St. Martin's Press.

Parsons, Wayne (2008). Public Policy:Pengantar Teori dan Praktik Analisis Kebijakan, Terjemahan Tri Wibowo Budi Santoso, Jakarta: Kencana Prenada Media Group.

Robbins, Stephen P \& Coulter, Mary. (2012). Management.England : Pearson. 